\title{
EFFECTS OF CUTTING PARAMETERS ON QUALITY OF SURFACE PRODUCED BY MACHINING OF TITANIUM ALLOY AND THEIR OPTIMIZATION
}

\begin{abstract}
Titanium alloy (Ti-6Al-4V) has been extensively used in aircraft turbine-engine components, aircraft structural components, aerospace fasteners, high performance automotive parts, marine applications, medical devices and sports equipment. However, wide-spread use of this alloy has limits because of difficulty to machine it. One of the major difficulties found during machining is development of poor quality of surface in the form of higher surface roughness. The present investigation has been concentrated on studying the effects of cutting parameters of cutting speed, feed rate and depth of cut on surface roughness of the product during turning of titanium alloy. Box-Behnken experimental design was used to collect data for surface roughness. ANOVA was used to determine the significance of the cutting parameters. The model equation is also formulated to predict surface roughness. Optimal values of cutting parameters were determined through response surface methodology. A 100\% desirability level in the turning process for economy was indicated by the optimized model. Also, the predicted values that were obtained through regression equation were found to be in close agreement to the experimental values.
\end{abstract}

\section{Introduction}

Machining is one of the most extensively used manufacturing processes to give desired shape to the material as per design criteria. The term machining is used to cover chip forming operations by removal of unwanted material from the product. The productivity and accuracy of metal removal operations are governed

\footnotetext{
${ }^{1}$ School of Mechanical Engineering, Galgotias University, Greater Noida, UP, India. Emails: vietgkp100@yahoo.com,banshiprasad@gmail.com

${ }^{2}$ Department of Mechanical Engineering, Hindustan College of Science \& Technology, Farah, Mathura, UP, India.Email: khaniqbalahmed@yahoo.com

${ }^{3}$ Mechanical Engineering Department, Jamia Milia Islamia University, New Delhi, India. Email: zakhanusm@yahoo.com
} 
by machining process parameters, cutting conditions and cutting tool geometry, as well as combination of material of the work piece and cutting tool [1].

Rapid progress in the science and technology of materials has resulted in the development of a wide range of advanced engineering materials. These materials are customized to attain special characteristics required by applications such as high strength-to-weight ratio, high strength at elevated temperatures, excellent surface finish. One of the categories of this group is titanium-based alloy. Although these materials are being extensively used in wide range of engineering applications such as aerospace, medical, petroleum, they are difficult to machine, and their properties impose a lot of constraints in manufacturing. These constraints can be lack of appropriate machining technology to take advantage of advanced materials, and there is a great need for reliable and cost effective machining processes [1]. One way to achieve cost effectiveness in machining of advanced materials is by elongating tool life by reducing replacements of tool and the resources used in machining. Tool wear causes degradation of the shape and efficiency of tool cutting edge and this influences the surface quality, dimensional accuracy of the finished product.

Titanium alloys are extensively used due to its superior properties of low density, high strength to weight ratio, good temperature resistance and corrosion resistance. These properties reduce its machinability. This has limited the cutting tools to coated carbides and cemented carbide tools and prevents the use of high cutting speeds. The poor machinability of titanium alloys is due to their low thermal conductivity which increases the temperature at the cutting tool and the work piece creating a very high temperature of the cutting zone. Additionally, the interface between titanium chips and cutting tools is usually quite small, which results in high cutting zone stresses. There is also a strong tendency of the chips to get welded to the cutting tools leading to production of inferior surface roughness. It can be considered in any application where a combination of high strength at low to moderate temperatures, light weight and extra corrosion resistance are required. Some of the applications where this alloy can be used include aircraft turbine engine components, aircraft structural components, aerospace fasteners, high performance automotive parts, marine applications, medical devices and sports equipment. Since titanium does not react with human body, it is used to create artificial parts of human body like pins for setting bones and for biological implants. It can also be used in motorsport [1].

The product nowadays demands better surface roughness and hence surface finish. The better surface finish and reduction of cutting temperature can be achieved through the use cutting fluids like servo oil and synthetic oil. Synthetic oil is more effective for these under high cutting speed, high depth of cut and low feed rate [2]. Feed rate plays dominant parameter under dry, servo cut oil and water and synthetic oil conditions in optimizing the surface roughness [3]. In this paper, one study is surface integrity in dry high speed turning of Ti-6Al-4V. The increase in cutting speed causes reduction in surface roughness under dry high speed turning of Ti-6Al-4V. It is observed that a variety of alterations/defects such as shallow 
grooves, micro-particles deposits and smeared layer are formed. The built-up edge is more common in dry machining or without the use of coolant. This problem can be eliminated with the use of coolant or with wet machining. The use of coolant during machining of titanium alloy prevents the formation of build-up edge and also reduces the heat generated at the interface and thus improves surface roughness [4]. The different parameters affecting surface roughness that are considered by researchers are cutting speed, feed rate, depth of cut and coolant [5]. Cutting velocity and feed provides primary contribution and influences most significantly on surface roughness [6]. A good surface finish of 0.5-1 micron was achieved for cutting speed between 15-45 m/min, feed of 0.1-0.2 mm/rev and depth of cut of $1 \mathrm{~mm}$ using CNMG insert. Nose radius also plays significant effect on surface roughness [7] during dry and wet machining of titanium alloy. The feed rate affects most significantly the surface roughness [8] during machining of aerospace titanium alloy. Also, S. Ramesh et.al [9] measured and analyzed the surface roughness in turning of aerospace titanium alloy (grade 5). They found that feed rate is the most significant factor affecting surface roughness. The surface roughness improves with the increase in cutting speed during the use of minimum quantity lubrication [10]. The titanium content in turning operation with carbide tool does not have any effect on surface roughness [11]. In case of ultra-precision cutting of titanium using diamond tool with small depth of cut, surface roughness has been found below $10 \mathrm{~nm}$ at lower feed rate $50 \mu \mathrm{m} / \mathrm{sec}$ [12]. The coated carbide inserts show better performance compared with uncoated carbide insert in terms of surface roughness [13].

It is found that hardly any literature is readily available regarding study of the effects of process parameters in detail during turning of titanium alloy of Ti-6Al-4V. Therefore, keeping this in mind, the present work has been planned to study various aspects of machining process during turning of Ti-6Al-4V under different process parameters to provide better insight into the factors affecting surface roughness of the product. By doing this, new cutting parameter zones can be proposed, which will be able to generate better surface roughness. In the design of experiment approach, one will consider the individual factors and the interactions while measuring the response.

\section{Experimentation}

Titanium alloy, Ti-6Al-4V (Grade5) of length $350 \mathrm{~mm}$ and diameter $40 \mathrm{~mm}$, was used as base material for conducting turning operation using various combination of cutting parameters. The chemical composition of the titanium alloy is

Chemical composition of titanium alloy

\begin{tabular}{|l|c|c|c|c|c|}
\hline Components & $\mathrm{Al}$ & $\mathrm{Fe}$ & $\mathrm{O}_{2}$ & $\mathrm{~V}$ & $\mathrm{Ti}$ \\
\hline Weight $\%$ & 6 & 0.25 & 0.2 & 4 & 90 \\
\hline
\end{tabular}


Table 2.

Cutting parameters and their levels

\begin{tabular}{|c|c|c|c|c|}
\hline Factors & Symbols & Level-1 & Level-2 & Level-3 \\
\hline \multicolumn{2}{|l|}{ Code Value } & -1 & 0 & +1 \\
\hline Cutting speed (m/min) & A & 90.1 & 150 & 239 \\
\hline Feed rate $(\mathrm{mm} / \mathrm{rev})$ & B & 0.1 & 0.15 & 0.2 \\
\hline Depth of cut (mm) & $\mathrm{C}$ & 0.2 & 0.5 & 0.8 \\
\hline
\end{tabular}

shown in Table 1. Coated cemented carbide inserts (PVD) were used to machine the alloy. The cutting inserts were coated with AlSiTiN at the top and the second layer of AlTiN, and had nose radius of $0.8 \mathrm{~mm}$. The tool holder used was designated as WIDIA ID 2L PCLNR 1616 H12. The machining parameters taken along with the three levels of each parameter are depicted in Table 2. Table 2 also gives the codes utilized for analysis. The experiments were conducted with different combination of possible three level of cutting parameters decided using the Box-Behnken Design of experiment, as shown in Table 3. Table 3 also contains the coded value corresponding to different levels of machining parameters in brackets. The work piece was divided into 17 equal parts of $20.5 \mathrm{~mm}$ each. The turning process with various combination of cutting parameters was carried out with a fresh insert.

Table 3.

Surface roughness under varying combination of cutting parameters of actual and coded value in bracket using Box Behnken Design

\begin{tabular}{|c|c|c|c|c|c|}
\hline Runs & $\begin{array}{c}\text { Cutting speed } \\
(\mathrm{m} / \mathrm{min})\end{array}$ & $\begin{array}{c}\text { Feed rate } \\
(\mathrm{mm} / \mathrm{rev})\end{array}$ & $\begin{array}{c}\text { Depth of } \\
\text { cut }(\mathrm{mm})\end{array}$ & $\begin{array}{c}\text { Measured surface } \\
\text { roughness }(\mu \mathrm{m})\end{array}$ & $\begin{array}{c}\text { Predicted surface } \\
\text { roughness }(\mu \mathrm{m})\end{array}$ \\
\hline 1 & $150(0)$ & $0.1(-1)$ & $0.2(-1)$ & 0.68 & 0.784275 \\
\hline 2 & $150(0)$ & $0.15(0)$ & $0.5(0)$ & 0.71 & 0.472763 \\
\hline 3 & $239(+1)$ & $0.15(0)$ & $0.2(-1)$ & 0.46 & 1.170015 \\
\hline 4 & $90.1(-1)$ & $0.15(0)$ & $0.8(+1)$ & 1.16 & 0.784275 \\
\hline 5 & $150(0)$ & $0.15(0)$ & $0.5(0)$ & 0.71 & 0.854585 \\
\hline 6 & $150(0)$ & $0.2(+1)$ & $0.8(+1)$ & 0.78 & 0.404853 \\
\hline 7 & $239(+1)$ & $0.1(-1)$ & $0.5(0)$ & 0.42 & 0.497353 \\
\hline 8 & $239(+1)$ & $0.2(+1)$ & $0.5(0)$ & 0.49 & 0.784275 \\
\hline 9 & $150(0)$ & $0.15(0)$ & $0.5(0)$ & 0.71 & 0.852185 \\
\hline 10 & $150(0)$ & $0.2(+1)$ & $0.2(-1)$ & 0.80 & 1.099705 \\
\hline 11 & $90.1(-1)$ & $0.1(-1)$ & $0.5(0)$ & 1.11 & 0.784275 \\
\hline 12 & $150(0)$ & $0.15(0)$ & $0.5(0)$ & 0.71 & 1.192205 \\
\hline 13 & $90.1(0)$ & $0.2(+1)$ & $0.5(0)$ & 1.19 & 1.167615 \\
\hline 14 & $90.1(-1)$ & $0.15(0)$ & $0.2(-1)$ & 1.17 & 0.762085 \\
\hline 15 & $150(0)$ & $0.1(-1)$ & $0.8(+1)$ & 0.69 & 0.784275 \\
\hline 16 & $150(0)$ & $0.15(0)$ & $0.5(0)$ & 0.71 & 0.475163 \\
\hline 17 & $239(+1)$ & $0.15(0)$ & $0.8(+1)$ & 0.48 & 0.784275 \\
\hline & & & & & \\
\hline
\end{tabular}


Before performing actual experiments, $2 \mathrm{~mm}$ material from the work piece was removed in order to remove any undulations. The experiments were carried out under wet conditions. The cutting fluid used was water soluble oil with $75 \%$ water and designated as Servo cut S lubricant oil. It has superior cooling and lubricating properties which impart excellent surface finish and minimizes tool wear. The lathe machine used in turning had the maximum spindle speed of $2000 \mathrm{rpm}$, as shown in Fig. 1. The chuck used to hold the job was a three-jaw chuck.

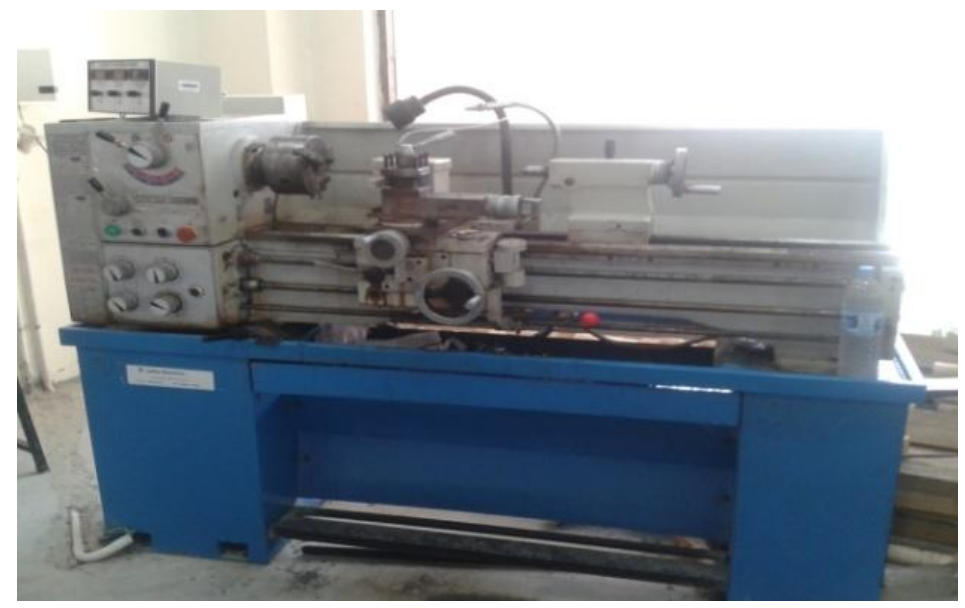

Fig. 1. Lathe machine used to conduct the experiment

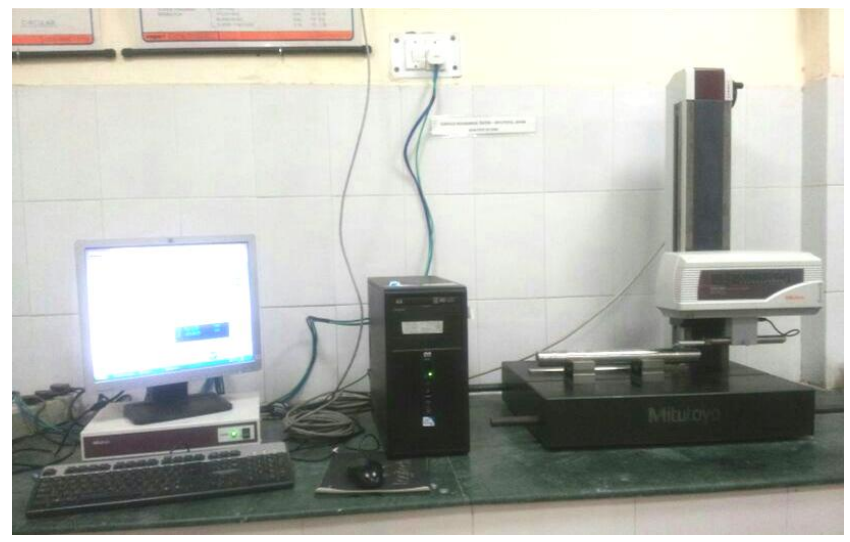

Fig. 2. Photograph of surface roughness measurement test set up

The arrangement for measurement of surface roughness is shown in Fig. 2. Measurement of surface roughness was done for all the pieces produced with various combinations of cutting parameters in the unit of micrometers. The surface roughness was measured using surface roughness tester from MITUTOYO JAPAN designated as SUR-FTEST SV-210 (Fig. 2). It has a diamond stylus mounted at 
the end of the probe and it thoroughly remains in contact with the surface being measured during its transverse by a specified distance.

Response surface methodology based on the Box-Behnken design was used for optimization of results and analysis, as it provides more advantages over other methods of design. A systematic procedure was provided by the Response Surface Methodology for determining relationship between cutting parameters and output.

\section{Results and discussions}

Machining of titanium alloy round specimen having diameter $40 \mathrm{~mm}$ by turning was done using various combination of parameters decided by the Box-Behnken design of experiment. The quality of the work piece depends on the surface finish produced by the machining methods utilized. The surface finish is often measured in the form of surface roughness, which is average departure of the surface from perfection over a prescribed sampling length. The surface roughness measurements were made along a line running at right angle to the general direction of tool marks on the surface. Surface roughness has significant effect on interaction between a product and the environment in which it is put to service during use. A rough surface wears relatively more quickly and has higher coefficient of friction than smooth surface. Surface roughness can also be considered as a predictor of the performance of a mechanical component, as irregularities in the surface may form nucleation sites for cracks or corrosion. Therefore, the surface roughness is studied and measured during turning of titanium alloy and expressed in the form of $R_{a}$. The $R_{a}$ denotes surface roughness number expressed as average variation of surface from perfection. The measured surface roughness of the work pieces is depicted in Table 3. The surface roughness values thus obtained are analyzed and optimized with the help of ANOVA utilizing response-surface methodology.

Response-surface methodology is a statistical and mathematical method used to optimize the response surface that is influenced by various process parameters. It also establishes the relationship between the input parameters and the obtained response surfaces. The design procedure of response-surface methodology is summarized as follows

1. Designing of a series of experiments for adequate and reliable measurement of the response of interest.

2. Developing a mathematical model of the second-order response surface with the best fit.

3. Finding the optimal set of experimental parameters that produce a maximum or minimum value of response.

4. Representing the direct and interactive effects of process parameters through two and three dimensional plots.

The surface roughness is minimized using response-surface methodology. In this method, generally a second-order model is utilized, as higher-order terms 
are insignificant. Accordingly, the effect of parameters of machining on surface roughness can be explained with the help of the following quadratic equation

$$
Y=\beta_{0}+\sum \beta_{i} X_{i}+\sum \beta_{i i} X_{i}^{2}+\sum \beta_{i j} X_{i} X_{j}
$$

where $Y$ is the predicted response of surface roughness, $\beta_{0}$ the offset term, $\beta_{i}$ the linear effect, $\beta_{i i}$ the squared effect and $\beta_{i j}$ the interaction effect. $X_{1}, X_{2}, X_{3} \ldots$ are the parameters of machining influencing surface roughness. The $\beta$ coefficients, to be determined as second order model, are determined by least square method. For statistical calculation, the experimental variables $x_{i}$ have been coded as $X_{i}$ as per following transformation equations.

$$
X_{i}=\frac{x_{i}-x_{0}}{\delta x}
$$

where $X_{i}$ is the dimensionless coded value of the variable $x_{i}, x_{0}$ is the value of $x_{i}$ at the center point and $\delta_{x}$, the step change. Accordingly, the results of analysis are presented subsequently.

\subsection{ANOVA Full Model for Surface Roughness}

The results obtained from ANOVA full model for surface roughness of turned Ti-6Al-4V alloy are shown in Table 4. The table shows the values of sum of squares, df, mean square, F-value and P-value. The sum of squares denotes the total sum of squares of deviations of all the surface roughness from its mean value. The $\mathrm{df}$ shows number of degrees of freedom associated with sample variance. The sample variance is also considered as mean square because, it is obtained by dividing the sum of squares with the respective degree of freedom. F-value shows the test for comparing model variance with residual (error) variance. If the variances are close to same, the ratio will be close to one and it is less likely that any of the factors

ANOVA results for surface roughness (full model)

\begin{tabular}{|c|c|c|c|r|c|}
\hline Source & Sum of squares & df & Mean square & F-value & P-value \\
\hline Model & 1.02 & 9 & 0.11 & 1266.58 & 0.0001 \\
\hline A & 0.97 & 1 & 0.97 & 10819.76 & 0.0001 \\
\hline B & 0.017 & 1 & 0.017 & 191.66 & 0.0001 \\
\hline C & $1.250 \mathrm{E}-005$ & 1 & $1.250 \mathrm{E}-005$ & 0.14 & 0.7194 \\
\hline AB & $2.500 \mathrm{E}-005$ & 1 & $2.500 \mathrm{E}-005$ & 0.28 & 0.6131 \\
\hline AC & $2.250 \mathrm{E}-004$ & 1 & $2.250 \mathrm{E}-004$ & 2.52 & 0.1564 \\
\hline BC & $1.000 \mathrm{E}-004$ & 1 & $1.000 \mathrm{E}-004$ & 1.12 & 0.3251 \\
\hline A2 & 0.030 & 1 & 0.030 & 340.72 & 0.0001 \\
\hline B2 & $2.268 \mathrm{E}-004$ & 1 & $2.368 \mathrm{E}-004$ & 2.65 & 0.1474 \\
\hline C2 & $2.132 \mathrm{E}-003$ & 1 & $2.132 \mathrm{E}-003$ & 23.87 & 0.0018 \\
\hline
\end{tabular}

Table 4. 
have significant effect on surface roughness. This is calculated by dividing mean square with residual mean square. The "Prob $>F$ " is $P$ value for whole model test. If "Prob $>F$ " is less than 0.05 , one can reject the null hypothesis concluding that there are differences between at least two means. Accordingly, if "Prob $>F$ " has very small value of less than 0.05 , than the parameter's term in the model has a significant effect on surface roughness. Therefore, it can be said that if values of "Prob>F" are less than 0.0500 , more than 0.1000 and between 0.0500 and 0.1000 than the model terms are most significant, insignificant and significant, respectively. It is observed from Table 4 that the "Prob>F" i.e. P value for cutting speed (A), feed rate (B) and the quadratic terms $\mathrm{A}^{2}$ is 0.0001 being less than 0.05 . This shows that these have most significant effects on surface roughness, while for the depth of cut $(C)$, interactions of cutting speed and feed rate $(\mathrm{AB})$, cutting speed and depth of cut (AC), feed rate and depth of cut (BC) and square of feed rate, the value of "Prob $>F$ " is greater than 0.1 depicting no significant effect on surface roughness of these interaction. Further, the "Prob>F" for square of depth of cut $\left(C^{2}\right)$ is 0.0018 , again being less than 0.05 , and so may have significant effect on surface roughness of the machined product.

$\mathrm{R}^{2}$ and Adeq precision values

Table 5 .

\begin{tabular}{|l|r|}
\hline \multicolumn{2}{|c|}{ Surface roughness } \\
\hline R squared & 0.9994 \\
\hline Adeq precision & 108.664 \\
\hline
\end{tabular}

The R-Squared and Adeq Precision value of the surface roughness are depicted in Table 5. The R-Squared is called the coefficient of determination. It can be obtained by taking ratio of sum of squares explained by model to the total sum of squares around mean. It will show the measure of amount of variation of surface roughness around the mean explained by model. Adeq Precision is the measure of contrast in predicted response relative to its associated error or signal to noise ratio. It compares the range of predicted values at the designed points to the average prediction error. The ratio greater than 4 indicates adequate model discrimination. It is observed from Table 5 that the R-Squared value is 0.9994 for surface roughness. This high value is close to 1 which is desirable, as it indicates that the value of surface roughness obtained by model will be near to mean. It is further understood that the Adeq Precision ratios is " 108.664 ", which is much greater than 4 , indicating less associated error, and so it is desirable.

$$
\begin{gathered}
Y_{S R F A}(\text { Codedfactor })=+0.71-0.35 A+0.046 B+1.250 e^{-003} C \\
-2.500 e^{-003} A B+ \\
+7.500 e^{-003} A C-5.000 e^{-003} B C+0.085 A^{2} \\
+7.500 e^{-003} B^{2}+0.023 C^{2}
\end{gathered}
$$




$$
\begin{gathered}
Y_{S R F A}(\text { Actualfactor })=+1.187-9.782 e^{-003} A+0.302 B-0.251 C \\
-6.712 e^{-004} A B+3.258 e^{-004} A C-0.333 B C \\
+1.534 e^{-005} A^{2}+3.000 B^{2}+0.250 C^{2}
\end{gathered}
$$

where $Y_{S R F A}$ (Codedfactor) and $Y_{S R F A}$ (Actualfactor) denote the surface roughness in terms of coded factor and actual factor, respectively, for ANOVA full model. A, $\mathrm{B}$ and $\mathrm{C}$ represents the machining parameters of cutting speed, feed rate and depth of cut respectively.

\subsection{Reduced ANOVA Model for Surface Roughness}

As it is discussed in section 3.1 that the depth of cut (C), interactions of cutting speed and feed rate $(A B)$, cutting speed and depth of cut (AC), feed rate and depth of cut $(\mathrm{BC})$ and square of feed rate do not have any significant effect on surface roughness, these can be eliminated from the model. The reduced model of ANOVA, after eliminating these insignificant terms from full model, is shown in Table 6.

Reduced ANOVA model for surface roughness

\begin{tabular}{|c|c|c|c|r|c|}
\hline Source & Sum of squares & Df & Mean square & F-value & P-value \\
\hline Model & 1.02 & 5 & 0.20 & 1846.64 & 0.0001 \\
\hline A & 0.97 & 1 & 0.97 & 8768.92 & 0.0001 \\
\hline B & 0.017 & 1 & 0.017 & 155.33 & 0.0001 \\
\hline C & $1.250 \mathrm{E}-005$ & 1 & $1.250 \mathrm{E}-005$ & 0.11 & 0.7426 \\
\hline A2 & 0.031 & 1 & 0.031 & 279.48 & 0.0001 \\
\hline C2 & $2.213 \mathrm{E}-003$ & 1 & $2.213 \mathrm{E}-003$ & 20.29 & 0.0009 \\
\hline
\end{tabular}

Table 6.

It is understood that the value of "Prob>F" i.e. P-value for the cutting speed (A), feed rate $(\mathrm{B})$ and quadratic term $\left(\mathrm{A}^{2}\right)$ is 0.0001 . This is less than 0.05 depicting that these factors have most significant effect on surface roughness. Further, the value of "Prob $>F$ " for depth of cut (C) is 0.7426 showing the insignificant effect on surface roughness, as it is greater than 0.1. The values of R Squared, Adj R Square and Pred R Square for the reduced ANOVA model are shown in Table 7. The R Squared shows a measure of the amount of variation around the mean explained by the model. The Adj R Square is a measure of the amount of variation around the mean explained by the model, adjusted for the number of terms in the model. The

\begin{tabular}{|l|r|}
\multicolumn{2}{c|}{$\mathrm{R}^{2}$ Adj $\mathrm{R}^{2}$ Pred $\mathrm{R}^{2}$} \\
\hline \multicolumn{2}{|c|}{ Surface roughness } \\
\hline $\mathrm{R}$ squared & 0.9988 \\
\hline Adj R Square & 0.9983 \\
\hline Pred R Square & 126.291 \\
\hline
\end{tabular}

Table 7 . 
adjusted R-squared decreases as the number of terms in the model increases, if those additional terms don't add value to the model. Pred R Square is a measure of the amount of variation in new data explained by the model. The predicted R-Squared and the Adjusted R-squared should be within 0.20 of each other. Otherwise, there may be a problem with either the data or the model. This model can be used to navigate the design space. The final empirical model for surface roughness in terms of the coded factor and the actual factor are given in equations 5 and 6 , respectively.

$$
\begin{aligned}
Y_{S R F A}(\text { Codedfactor }) & =+0.71-0.35 A+0.046 B+1.250 e^{-003} C \\
& +0.085 A^{2}+0.023 C^{2} \\
Y_{S R F A}(\text { Actualfactor })= & +1.181-9.738 e^{-003} A+0.925 B-0.251 C \\
+ & 1.541 e^{-005} A^{2}+0.254 C^{2}
\end{aligned}
$$

where $Y_{S R R A}$ (Codedfactor) and $Y_{S R R A}$ (Actualfactor) represent the surface roughness in terms of the coded factor and the actual factor, respectively, for ANOVA reduced model.

\subsection{Plots for Surface Roughness}

a) Normal plot of probability of residuals. Fig. 3 shows the normal probability plot of residuals of surface roughness. The normal probability plot indicates whether the residuals follow a normal distribution in which the points will follow a straight line. There can be some scatter even with normal data. It is observed that the

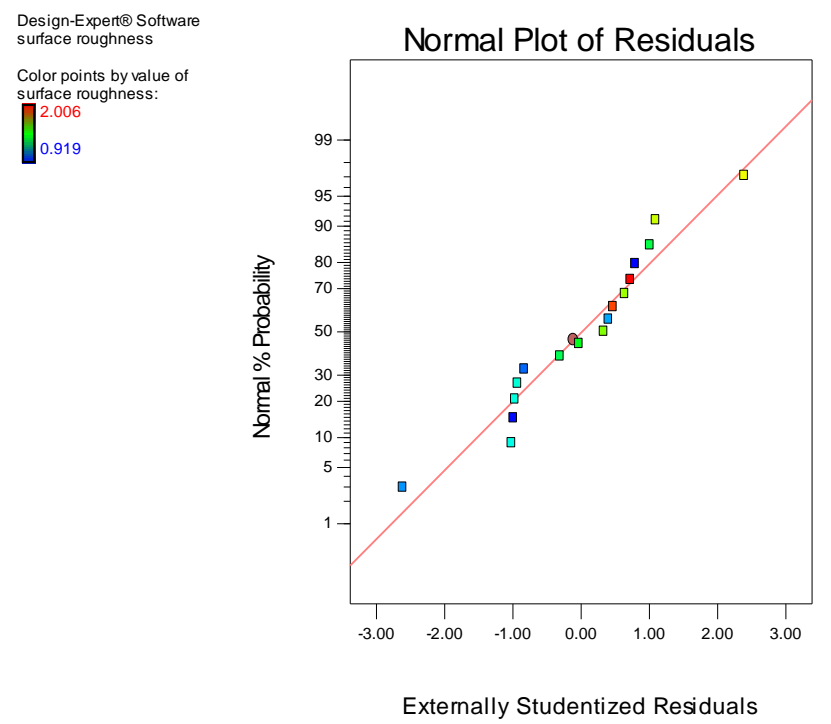

Fig. 3. Normal probability plot for surface roughness 
residuals either fall on a straight line or lie very close to the line. This shows that the errors are normally distributed.

b) Plot of residuals versus predicted. The plot of residuals versus predicted for surface roughness is shown in Fig. 4. This is a plot of the residuals versus the ascending predicted response values of surface roughness. It tests the assumption of constant variance. Expanding variance in this plot shows the requirement for a transformation. It is understood that the residuals standardized with respect to the predicted values of surface roughness do not show any obvious pattern and are distributed in both positive and negative directions. This implies that the model is adequate.

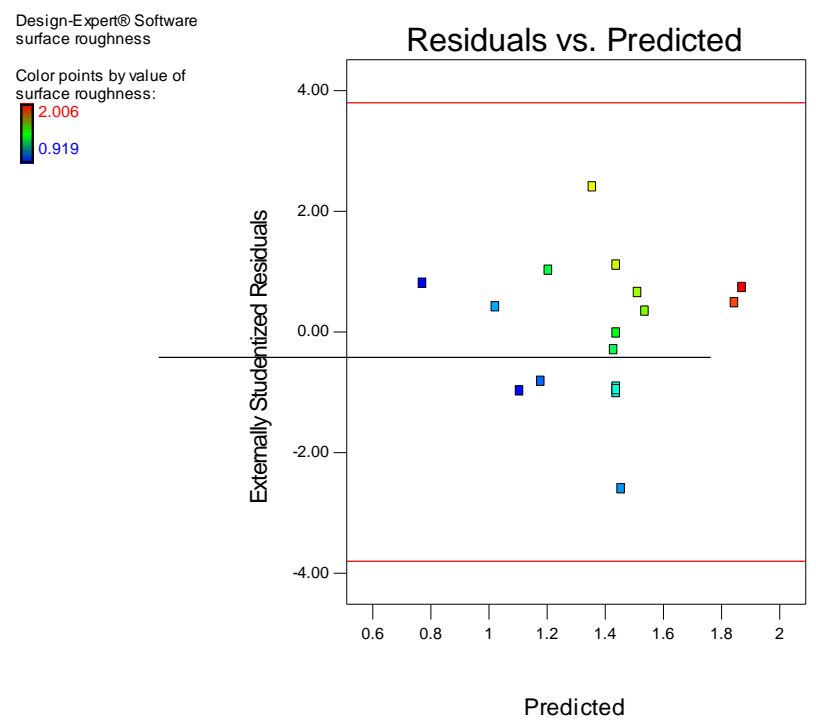

Fig. 4. Residuals v/s predicted values

c) Comparison of measured and predicted values for surface roughness. The comparison between the experimental values and predicted values from regression Eqn. 6 is depicted in Fig. 5. For comparison, the different combination of parameters of machining of cutting speed, feed rate and depth of cut, and corresponding measured experimental values of surface roughness are taken into consideration as shown in Table 3. Further, the predicted values of surface roughness have been obtained using same combination of parameters as depicted in Table 3 and with the help of Eqn. 6. Accordingly, the machining parameters, the measured and predicted surface roughness of the machined components are shown in the same Table 3. It is observed that the values of surface roughness obtained using equation 6 are very close to the values measured through experiment. This confirms the validity of the equations obtained through empirical model, which can be employed to find the surface roughness for Ti-6Al-4V alloy during machining of it. 


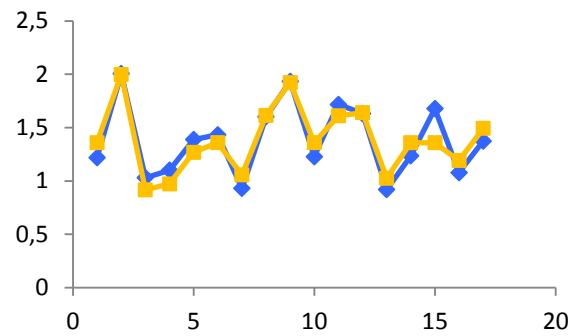

Fig. 5. Experimental verses Predicted Values of surface roughness in units of $\mu \mathrm{m}$

d) Perturbation plot for surface roughness. The perturbation plot for surface roughness is shown in Fig. 6. The surface roughness is found out using the codes shown in Table 3. Perturbation plots help one to compare the effect of all the factors of cutting speed, feed rate and depth of cut at a particular point in the RSM design space. The response of surface roughness is plotted by changing only one factor over its range, while keeping all other factors constant. In the present analysis, the reference point is taken at the midpoint (coded 0) of all of the factors. It is understood that the slope of the curve A-A for cutting speed is relatively higher as compared to either of the curves B-B and C-C which are for feed rate and depth of cut. This indicates that the effect of cutting speed on surface roughness of the machined component is comparatively higher relative to feed rate or depth of cut. It can also be stated that the curve for depth of cut C-C is almost horizontal indicating further insignificant effect of it on surface roughness of the component.

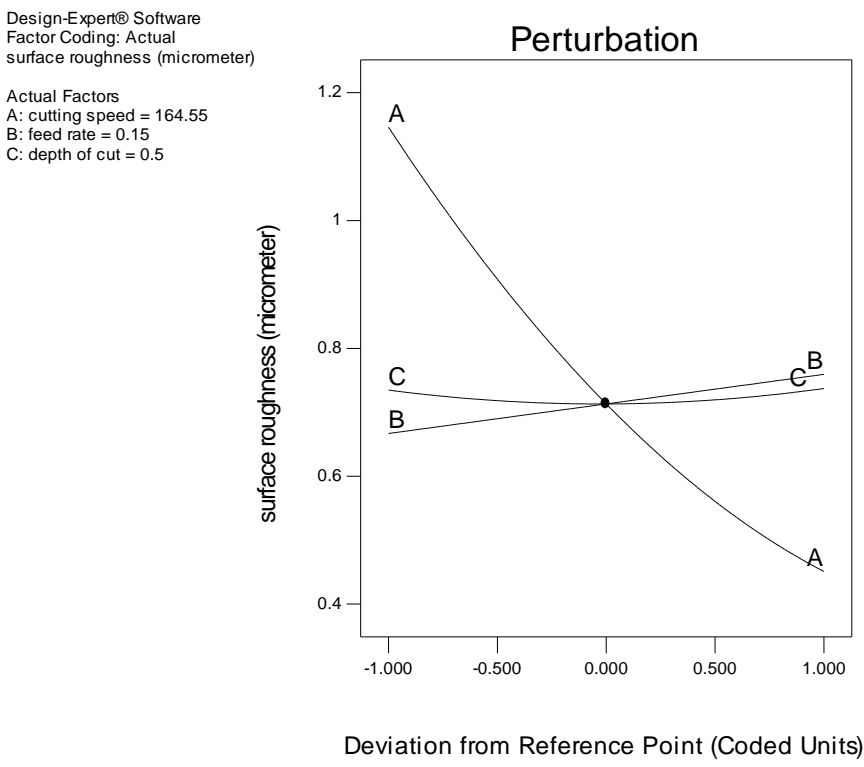

Fig. 6. Perturbation plot for surface roughness 
The perturbation plot for surface roughness shows that surface roughness decreases with the increase in cutting speed, increases with the increase in feed rate and it decreases with the decrease in depth of cut.

\subsection{Inference of the Plots}

The surface plot of surface roughness vs. feed rate and cutting speed, surface roughness vs. depth of cut and cutting speed and surface roughness vs. depth of cut and feed rate are depicted in Fig. 7 (a), (b), and (c). It is observed that the surface roughness decreases giving rise to superior surface quality with an increase in cutting speed to a higher level. This is because of heat generated due to turning operation. Some part of the heat generated during machining by turning operation will go to the work piece resulting in the thermal softening effect in the machining region causing restructuring of near surface layer ultimately producing poor surface finish. It is further observed that the surface roughness increases leading to inferior surface quality with enhancement of feed rate. It is also understood that the surface roughness enhances slightly with the reduction of depth of cut, but it affects relatively less the surface roughness. This happens because, at lower depth of cut, the deformation is slow, which results in higher strains and strain rate in the machining region as a consequence of non-uniform deformation of the machined surface, leading to slightly higher surface roughness [3]. In order to obtain a given surface finish and maximum metal removal, it is suggested to use relatively higher feed rate associated with larger depth of cut.

\subsubsection{Effect of cutting speed}

From ANOVA analysis (Table 4), it can be seen that cutting speed has a noticeable contribution (17.49\%) in minimizing the surface roughness. From Fig. 7, it is understood that the surface roughness of the machined component decreases with increased cutting speed. This is due to the fact that high spindle speed is associated with the higher cutting temperature, increasing the softening of the work piece material and then reducing the cutting forces and hence leading to better surface finish. A similar result was also reported by Che-Haron and Jawaid [17] during machining of Ti 6Al-4V alloy with 883 inserts under dry cutting conditions, where low surface roughness was obtained with the increase in cutting speed. In addition, at higher spindle speed, the chip will break away with less material deformation at the immediate tool tip, which in turn preserves the machined surface properties leading to minimal surface roughness. However, it is believed that the spindle speed should be controlled at an optimum value, as the influence of high temperature would significantly affect the chip formation mode, cutting forces, tool life and surface roughness. The surface roughness could be improved by increasing cutting speed, though the improvement is very limited at higher cutting speed (100-150 m/min). Producing an enhanced surface finish at elevated cutting 


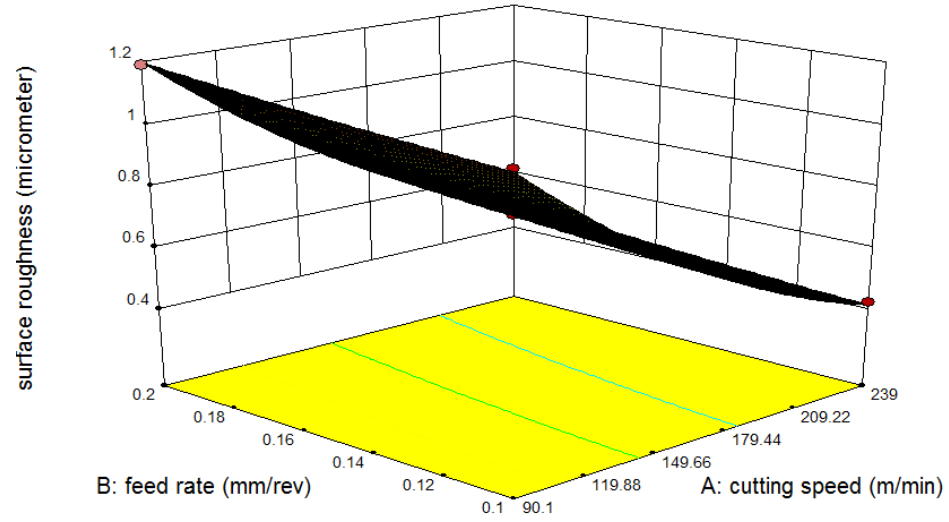

(a)

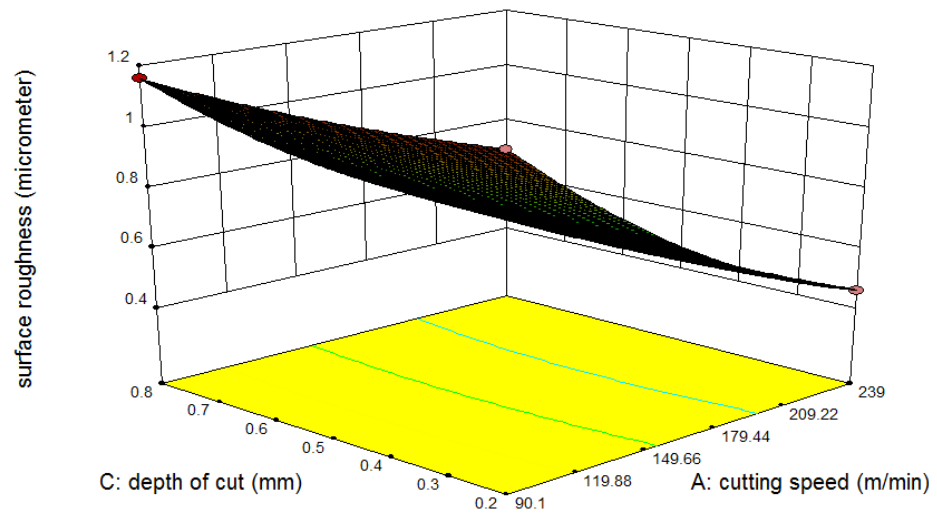

(b)

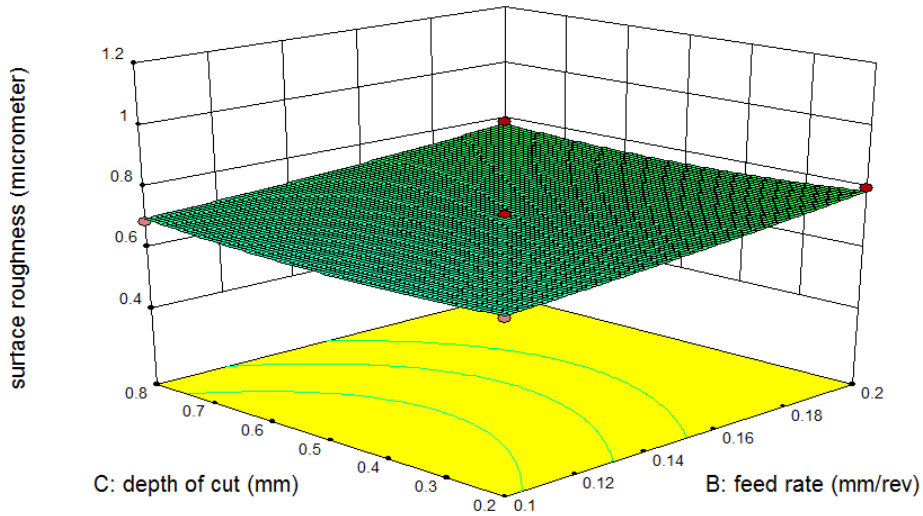

(c)

Fig. 7. Surface plot of (a) surface roughness v/s feed rate and cutting speed, (b) surface roughness $\mathrm{v} / \mathrm{s}$ depth of cut and cutting speed and (c) surface roughness v/s depth of cut and feed rate 
speed is eminent in metal cutting. The conventional explanations are related to built-up-edge (BUE); i.e., the formation of BUE is favored in a certain range of cutting speed. By increasing cutting speed beyond this region, BUE is eliminated resulting in improvement of surface finish. During current investigations on Ti$6 \mathrm{Al}-4 \mathrm{~V}$ alloy machining, the cutting speeds were higher than those favoring BUE formation. The deformation velocity influences the properties of the metals. The plastic behavior will be less important with higher velocity. If the material presents less plasticity, by increasing cutting speed and hence deformation velocity one can improve the surface finish as a result of less significant lateral plastic flow and thus less additional increase in the peak-to-valley height of the machined surface roughness $[14,15]$. In addition, at low cutting speed, grooves are developed on the tool wear face. Larger the development of the grooves, the more significant deterioration of the surface finish takes place.

\subsubsection{Effect of feed rate}

From ANOVA (Table 4), it is seen that feed rate has also noticeable contribution $(72.32 \%)$ in minimizing the surface roughness. In general, as feed rate increases, the surface roughness also increases for dry, flooded and minimum quantity lubricating (MQL) conditions. However, MQL shows reduction in surface roughness when compared to dry and flooded condition under different feed rates due to the MQL delivery pressure applied, which in turn will remove chips (debris) from the cutting zone. As can be seen from Fig. 7, as the feed rate increases, the surface roughness also increases because of less available time to carry out the heat from the cutting zone, high amount material removal rate and an accumulation of chip between the tool-work piece zones.

\subsubsection{Effect of depth of cut}

It is quite evident from Fig. 7 that the surface roughness increases slightly with increased depth of cut, mainly due to an increase in thermal load and vibration on the machine tool. Further, due to more contact area between tool and work piece, high friction and tool wear exist, hence leading to high surface roughness. It is recommended to use low depth of cut to reduce the chatter, which subsequently leads to good surface finish. Our findings also closely agree with the experimental results reported in literature [16].

\subsection{Optimization of Cutting Parameters}

The optimization was carried out through the Box-Behnken Design. Desirability function optimization of the RSM has been employed for single response optimization. The objective function of the optimization is called the desirability function that reflects level of each response in terms of minimum (zero) to 
maximum (one) desirability. In the Response Surface methodology of present investigation, desirability function optimization represents the optimization of the objective function of surface roughness. For simultaneous optimization, each variable and response must have a low and high value assigned to each objective. Then, the input parameters will come in range that keeps the solution within the experimental limits. The use of the response surface optimization helps us to find the optimal values of cutting parameters in order to minimize surface roughness during the turning of titanium alloy. The purpose of optimization is to minimize surface roughness and find the range of cutting parameters, as is clear from Table 8 .

Table 8 .

Goals and conditions for optimization of surface roughness

\begin{tabular}{|l|l|c|c|}
\hline Condition & Goal & Lower limit & Upper limit \\
\hline Cutting speed & In range & 90.1 & 239 \\
\hline Feed rate & In range & 0.1 & 0.2 \\
\hline Depth of cut & In range & 0.2 & 0.8 \\
\hline Surface roughness & Minimize & 0.414 & 0.415 \\
\hline
\end{tabular}

The results of the optimization are shown in Table 9. It is observed that the optimum value of cutting parameters of cutting speed, feed rate and depth of cut are in the range of $(235.803 \mathrm{~m} / \mathrm{min}-235.916 \mathrm{~m} / \mathrm{min}),(0.102 \mathrm{~mm} / \mathrm{rev}-0.103 \mathrm{~mm} / \mathrm{rev})$ and $(0.241 \mathrm{~mm}-0.276 \mathrm{~mm})$, respectively, giving rise to surface roughness of the order of $0.414 \mu \mathrm{m}$.

Table 9.

Optimization of surface roughness

\begin{tabular}{|c|c|c|c|c|}
\hline No. & $\begin{array}{c}\text { Cutting speed } \\
\mathrm{m} / \mathrm{min}\end{array}$ & $\begin{array}{c}\text { Feed rate } \\
\mathrm{mm} / \mathrm{rev}\end{array}$ & $\begin{array}{c}\text { Depth of cut } \\
\mathrm{mm}\end{array}$ & $\begin{array}{c}\text { Surface } \\
\text { roughness }\end{array}$ \\
\hline 1 & 238.209 & 0.106 & 0.395 & 0.415 \\
\hline 2 & 238.202 & 0.103 & 0.476 & 0.414 \\
\hline 3 & 235.803 & 0.104 & 0.447 & 0.420 \\
\hline 4 & 238.785 & 0.105 & 0.276 & 0.418 \\
\hline 5 & 236.326 & 0.104 & 0.468 & 0.419 \\
\hline 6 & 238.083 & 0.108 & 0.316 & 0.419 \\
\hline 7 & 238.987 & 0.106 & 0.292 & 0.416 \\
\hline 8 & 238.274 & 0.102 & 0.241 & 0.420 \\
\hline 9 & 235.916 & 0.103 & 0.366 & 0.419 \\
\hline 10 & 237.097 & 0.102 & 0.485 & 0.416 \\
\hline
\end{tabular}




\section{Conclusions}

The effect of cutting parameters of cutting speed, feed rate, and depth of cut on surface roughness during machining of titanium alloy (Ti-4Al-6V) were analyzed using the Response Surface Methodology. Based on the results and analysis, the following conclusions can be drawn

1. The Box-Behnken design based on the Response Surface Methodology can be used to model the relationship between cutting parameters and surface quality in the form of surface roughness.

2. The surface roughness is influenced principally by the cutting speed and feed rate and the quadratic term of cutting speed.

3. The optimized value of cutting parameters are of the order of cutting speed, $235.8 \mathrm{~m} / \mathrm{min}$, feed rate, $0.102 \mathrm{~mm} / \mathrm{rev}$ and depth of cut, $0.24 \mathrm{~mm}$, respectively, giving rise to surface roughness of order of $0.414 \mu \mathrm{m}$.

Manuscript received by Editorial Board, December 09, 2015;

final version, September 11, 2016.

\section{References}

[1] Azza Rashid Al Hasaani. Modelling of tool wear during turning of Ti-6Al-4V titanium alloy. Master Thesis, American University of Sharjah, United Arab Emirates, February 2013.

[2] M. Venkata Ramana, K. Srinivasulu and G. Krishna Mohan Rao. Performance evaluation and selection of optimal parameters in turning of Ti-6Al-4V under different cooling conditions. International Journal of Innovative Technology and Creative Engineering, 1(5):10-21, 2011.

[3] R. Pawar and R. Pawade. Surface integrity analysis in dry high speed turning of titanium alloy. In International Conference on Trends in Industrial and Mechanical Engineering (ICTIME,2012), pages 190-199, Dubai, 2012.

[4] M. Namb and D. Paulo. Influence of coolant in machinability of titanium alloy (Ti-6Al-4V). Journal of Surface Engineered Materials and Advanced Technology, 1(1):9-14, 2011.

[5] K. Goyal Srajan, R. Vignyagamoorthy and M. Antony Xavior. Effects of cutting parameters on surface roughness during turning of Ti-6Al-4V alloy. International Journal of Current Research, 4(11):181-185, 2012.

[6] N. Andriya, P. V. Rao and S. Ghosh. Dry Machining of Ti6Al4V alloy using PVD coated TiAlN tools. In Proceedings of the World Congress on Engineering, pages 1492-1497, London, UK, 2012.

[7] R. Dillibabu, K. Siva Sakthivel and S. Vinod Kumar. Optimization of process parameters in dry and wet machining of Ti-6Al-4V ELI using Taguchi Method. International Journal of Design and Manufacturing Technology, 4(3):15-21, 2013.

[8] R. Vinayagamoorthy and M. Anthony Xavior. Significant the effect of cutting parameters on surface roughness in precision turning in Ti6Al4V. Middle-East Journal of Scientific Research, 17(11):1586-1590, 2013.

[9] S. Ramesh, L. Karunamoorthy and K. Palanikumar. Measurement and analysis of surface roughness in turning of aerospace titanium alloy (gr5). Measurement, 45(5):1266-1276, 2012.

[10] G.D. Revankar, R. Shetty, S.S. Rao and V.N. Gaitonde. Response surface model for surface roughness during finish turning of titanium alloy under minimum quantity lubrication. In Proceedings of International Conferences on Emerging Trends in Engineering and Technology, (ICETET 2013), pages 78-84, Patong Beach, Thailand, 7-8 December 2013. 
[11] Ashwin J. Makadia and J. I. Nanavati. Optimization of machining parameters for turning operations based on response surface methodology. Measurement, 46(4):1521-1529, 2013.

[12] S. Sakamoto, A. Shinozaki and H. Yasui. Possibility of ultra-precision cutting of titanium alloy with diamond tool. In 20th Annual Meeting of the American Society for Precision Engineering, ASPE 2005, Norfolk, VA, US, 2005.

[13] D.K. Patil and M.S. Sawant. A parametric study on performance of titanium alloy using coated and uncoated carbide insert in CNC turning. International Journal of Advanced Mechanical Engineering, 4(5):557-564, 2014.

[14] S. Yang, G. Zhu, J. Xu and Y. Fu. Tool wear prediction of machining hydrogenated titanium alloy Ti6A14V with uncoated carbide tools. The International Journal of Advanced Manufacturing Technology, 68(1):673-682, 2013.

[15] W. Wei, J. Xu, Y. Fu and S. Yang. Tool wear in turning of titanium alloy after thermo-hydrogen treatment. Chinese Journal of Mechanical Engineering, 25(4):776-780, 2012.

[16] F. J. Sun, S. G. Qu, Y. X. Pan, X. Q. Li, and F. L. Li. Effects of cutting parameters on dry machining Ti-6Al-4V alloy with ultra-hard tools. International Journal of Advanced Manufacturing Technology, 79(1):351-360, 2015.

[17] C.H. Che-Haron and A. Jawaid. The effect of machining on surface integrity of titanium alloy Ti-6\% Al-4\% V. Journal of Materials Processing Technology, 166(2):188-192, 2005.

\section{Badanie i optymalizacja parametrów skrawania wpływających na jakość powierzchni uzyskaną przy obróbce stopów tytanu}

Streszczenie

Stop tytanu (Ti-6Al-4V) jest szeroko stosowany do budowy elementów turbinowych silników lotniczych i innych podzespołów samolotów, elementów złącznych w technice lotniczej i astronautycznej, wysokiej jakości części samochodowych, w technice okrętowej i medycznej, a także w sprzęcie sportowym. Niemniej, powszechne zastosowanie tego stopu jest ograniczone trudnościami z jego obróbką. Jednym z podstawowych problemów jest niska jakość obrabianej powierzchni, która charakteryzuje się znaczną chropowatością. Przedstawiona praca jest poświęcona badaniu wpływu parametrów skrawania, takich jak szybkość skrawania, szybkość posuwu i głębokość skrawania na chropowatość powierzchni uzyskaną w procesie toczenia stopu tytanu. Przy zbieraniu danych nt. chropowatości powierzchni wykorzystano planowanie eksperymentu metodą Boxa-Behnkena. Do określenia poziomu istotności parametrów skrawania zastosowano metodę analizy wariancji, ANOVA. Sformułowano także równania modelu, pozwalającego przewidzieć chropowatość powierzchni. Optymalne wartości parametrów skrawania wyznaczono, stosując metodę powierzchni odpowiedzi (RSM). Wartości parametrów wyznaczone na podstawie równań regresji są bardzo bliskie wartościom uzyskanym eksperymentalnie. 